\title{
Morphological and morphometric variations of Dicrocoelium rileyi (Digenea: Dicrocoelidae) parasitizing Tadarida brasiliensis (Chiroptera: Molosiidae) in Mexico
}

\author{
JORGE FALCÓN-ORDAZ ${ }^{1}$, PABLO OCTAVIO-AGUILAR ${ }^{1,2}$ and ISABEL ESTRELLA-CRUZ ${ }^{1}$ \\ ${ }^{1}$ Laboratorio de Morfología Animal, Universidad Autónoma del Estado de Hidalgo, Ciudad Universitaria, \\ Carretera Pachuca Tulancingo, s/n, Km 4.5, 42184 Mineral de la Reforma, Hidalgo, México \\ ${ }^{2}$ Laboratorio de Genética, Universidad Autónoma del Estado de Hidalgo, Ciudad Universitaria, \\ Carretera Pachuca Tulancingo, s/n, Km 4.5, 42184 Mineral de la Reforma, Hidalgo, México
}

Manuscript received on May 2, 2018; accepted for publication on September 1, 2018

\begin{abstract}
How to cite FALCÓN-ORDAZ J, OCTAVIO-AGUILAR P AND ESTRELLA-CRUZ I. 2019. Morphological and morphometric variations of Dicrocoelium rileyi (Digenea: Dicrocoelidae) parasitizing Tadarida brasiliensis (Chiroptera: Molosiidae) in Mexico. An Acad Bras Cienc 91: e20180436. DOI 10.1590/0001-3765201920180436.
\end{abstract}

\begin{abstract}
Fifty-five adult Dicrocoelium rileyi Macy, 1931 parasitizing Tadarida brasiliensis (Geoffroy, 1824) from Durango, Nuevo Leon, Puebla, Zacatecas and Mexico State were morphologically described and morphometrically analyzed. To evaluate the degree of variation among populations from the five localities, 27 morphometric measures of this species were transformed into an orthogonal factor by principal component analysis (PCA), and a posterior comparison among populations was performed using discriminant analysis of principal components (DAPC). Significant differences were observed with exceptions between the Puebla - Zacatecas and Nuevo Leon - Mexico State populations when forming three groups with an $88 \%$ assignation. The Durango population was the most dissimilar population. These results show that the morphological traits of $D$. rileyi are variable among the populations in this study due to local intraspecific variation; however, some of the specimens present in the distinct localities may represent different species. Molecular analysis is necessary to accurately define whether the populations involved in our study constitute one or several species.
\end{abstract}

Key words: Bats, Platyhelminthes, interlocal variability, multivariate analysis.

\section{INTRODUCTION}

Multivariate analysis provides statistical methods to study the joint relationships of variables in data that contain intercorrelations. Because several variables can be considered simultaneously, interpretations can be made that are not possible with univariate statistics due to the complexity of biological interactions (James and McCulloch 1990). In parasitology, multivariate analyses have

Correspondence to: Jorge Falcón-Ordaz

E-mail: profe_7864@uaeh.edu.mx

ORCid: http://orcid.org/0000-0003-3926-2254 been used to evaluate the morphometric patterns of several species of Digenea in different stages of development, for example, in cercariae (BenAbdallah et al. 2008, Chibwana and Nkwengulila 2009, Otachi et al. 2015, Caffara et al. 2016) and adults (Al-Zanbagi and Hassan 2013, AlemánMuñoz et al. 2013, Barger and Wellenstein 2015). Additionally, multivariate analyses can be used to compare morphologic variations among parasite populations (Chibwana and Nkwengulila 2009).

The genus Dicrocoelium Dujardin, 1845 consists of 19 species that parasitize the bile-ducts 
and gall-bladder (and more rarely, the pancreatic ducts or intestine) of birds and mammals and, rarely, reptiles and marsupials (Pojmanska 2008). Of the current total of species, 13 are parasites of mammals and six of birds (Macy 1931, Baer 1971, Panin and Zhatkanbaeva 1972, Hinaidy 1983, Cribb and Spratt 1992).

Dicrocoelium rileyi Macy (1931) was described from the bat Tadarida brasiliensis cynocephala (Le Conte, 1831) in Kansas and Oklahoma. This parasite has only been registered in T. brasiliensis distributed in the USA (Kansas, Oklahoma, Louisiana, New Mexico, Texas, and Florida) and Mexico (Morelos, Nuevo Leon, Zacatecas, Durango and Puebla) (Guzmán-Cornejo et al. 2003, Caspeta-Mandujano et al. 2017). There is currently no morphological and morphometric review of this species that would enable us to know of the existence of a species complex (Bray and Clers 1992). Therefore, the aim of the present work was to determine the degree of morphometric variability among five populations of $D$. rileyi in Mexico using discriminant analysis of principal components (DAPC) with a multivariate approach to determine the range of variation and to identify the diagnostic traits of the species.

\section{MATERIALS AND METHODS}

\section{SAMPLING}

Only one T. brasiliensis was collected at Hueypoxtla from the Municipality of Tequixquiac, Mexico

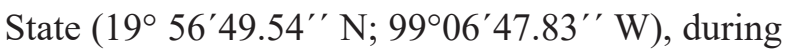
July 2016 under permit FAUT-0221 (Issued to A. E. Rojas-Martínez; Laboratorio de Ecología de Poblaciones, Centro de Investigaciones Biológicas, Universidad Autónoma del Estado de Hidalgo). Eight specimens of $D$. rileyi were found in the bile-ducts of this host. Worms were processed according to Guzmán-Cornejo et al. (2003) to unify the handling of our material with the techniques of the museum specimens deposited by these authors in the Colección Nacional de Helmintos (CNHE) of the Universidad Nacional Autónoma de Mexico (UNAM). Voucher specimens of helminths were deposited in CNHE 10798. Fifty-five adult specimens of $D$. rileyi underwent morphometric analysis, 47 of which were provided by the CNHE from the following locations: Nombre de Dios, Durango $\left(23^{\circ} 50^{\prime} 17^{\prime \prime} \mathrm{N}\right.$; 104 $14^{\circ} 41^{\prime \prime} \mathrm{W}$; $\mathrm{n}=9$ ), Cueva de la Boca, Santiago, Nuevo Leon $\left(25^{\circ} 24^{\prime} 55^{\prime \prime} \mathrm{N} ; 100^{\circ} 09^{\prime} 07^{\prime \prime} \mathrm{W} ; \mathrm{n}=14\right)$, Rio Salado, Zapotitlan de Salinas, Puebla (18 ${ }^{\circ}$ $20^{\prime} 00^{\prime \prime} \mathrm{N} ; 97^{\circ} 28^{\prime} 30^{\prime \prime} \mathrm{W} ; \mathrm{n}=12$ ) and Concepcion del Oro, Zacatecas $\left(24^{\circ} 37^{\prime} 02^{\prime \prime} \mathrm{N}\right.$; 101 ${ }^{\circ} 25^{\prime} 05^{\prime \prime} \mathrm{W}$; $\mathrm{n}=12$ ). Twenty-seven traits were measured for each digenean: body length (BL), maximal body width (BW), oral sucker length (OSL), oral sucker width (OSW), cirrus pouch length (CPL), cirrus pouch width (CPW), ventral sucker length (VSL), ventral sucker width (VSW), anterior testis length (ATL), anterior testis width (ATW), posterior testis length (PTL), posterior testis width (PTW), right vitellogenic gland length (RVGL), right vitellogenic gland width (RVGW), left vitellogenic gland length (LVGL), left vitellogenic gland width (LVGW), ovary length (OL), ovary width (OW), egg length (EL), egg width (EW), distance from the front of the anterior testis to the front of the body (DPAATPAB), distance from the posterior part of the testis to the front of the body (DPAPTPAB), distance from the right vitelline gland to the front of the body (DRVGPAB), distance from the right vitellogenic gland to the tail of the body (DRVGPPB), distance from the left vitellogenic gland to the front of the body (DLVGPAP), distance from the left vitellogenic gland to the tail of the body (DLVGPPB), and distance from the ovary to the front of the body (DOPAB). Measurements are given in micrometers (unless otherwise stated), with the range followed by the mean and standard deviation in parentheses (Figure 1 and Table I). 
TABLE I

Measurements of Dicrocoelium rileyi (based on 55 specimens) of Mexico. SD: Standard deviation, mm: millimeters, $n=$ Number of specimens.

\begin{tabular}{|c|c|c|c|c|c|}
\hline & $\begin{array}{c}\text { Durango } \\
n=9 \\
(\mathrm{CNHE} 3874- \\
\text { 3875) }\end{array}$ & $\begin{array}{c}\text { Puebla } \\
n=12 \\
(\text { CNHE 3872- } \\
\text { 3873) }\end{array}$ & $\begin{array}{c}\text { Nuevo León } \\
n=14 \\
\text { (CNHE3871) }\end{array}$ & $\begin{array}{c}\text { Zacatecas } \\
n=12 \\
\text { (CNHE3870) }\end{array}$ & $\begin{array}{c}\text { Mexico } \\
n=8 \\
\text { (CNHE10978) }\end{array}$ \\
\hline BL (mm) & $\begin{array}{c}2.15-2.52 \\
(2.34 \pm 0.14)\end{array}$ & $\begin{array}{c}1.67-2.52 \\
(2.17 \pm 0.29)\end{array}$ & $\begin{array}{c}1.45-2.32 \\
(1.87 \pm 0.27)\end{array}$ & $\begin{array}{c}1.05-3.07 \\
(2.36 \pm 0.64)\end{array}$ & $\begin{array}{c}1.92-2.85 \\
(2.25 \pm 0.36)\end{array}$ \\
\hline BW (mm) & $\begin{array}{c}0.27-0.5 \\
(0.38 \pm 0.06)\end{array}$ & $\begin{array}{c}0.25-0.42 \\
(0.33 \pm 0.05)\end{array}$ & $\begin{array}{c}0.37-0.77 \\
(0.49 \pm 0.10)\end{array}$ & $\begin{array}{c}0.15-0.45 \\
(0.35 \pm 0.09)\end{array}$ & $\begin{array}{c}0.2-0.35 \\
(0.28 \pm 0.4)\end{array}$ \\
\hline OSL & $\begin{array}{c}72.5-187.5 \\
(148.88 \pm 39.15)\end{array}$ & $\begin{array}{c}147.5-192.5 \\
(166.87 \pm 15.30)\end{array}$ & $\begin{array}{c}132.5-187.5 \\
(154.28 \pm 17.93)\end{array}$ & $\begin{array}{c}92.5-177.5 \\
(144.58 \pm 27.42)\end{array}$ & $\begin{array}{c}120-175 \\
(141.42 \pm 16.51)\end{array}$ \\
\hline OSW & $\begin{array}{c}70-172.5 \\
(136.11 \pm 32.43)\end{array}$ & $\begin{array}{c}132.5-180 \\
(154.37 \pm 13.94)\end{array}$ & $\begin{array}{c}110-180 \\
(132.5 \pm 18.73)\end{array}$ & $\begin{array}{c}75-162.5 \\
(128.75 \pm 26.89)\end{array}$ & $\begin{array}{c}110-147.5 \\
(121.42 \pm 15.8)\end{array}$ \\
\hline CPL & $\begin{array}{c}67.5-117.5 \\
(97.5 \pm 17.67)\end{array}$ & $\begin{array}{c}92.5-225 \\
(147.08 \pm 42.57)\end{array}$ & $\begin{array}{c}105-217.5 \\
(155.71 \pm 32.79)\end{array}$ & $\begin{array}{c}75-182.5 \\
(145 \pm 33.43)\end{array}$ & $\begin{array}{c}25-120 \\
(89.68 \pm 27.98)\end{array}$ \\
\hline CPW & $\begin{array}{c}50-65 \\
(57.5 \pm 6.32)\end{array}$ & $\begin{array}{c}47.5-132.5 \\
(90.62 \pm 29.67)\end{array}$ & $\begin{array}{c}45-190 \\
(72.85 \pm 34.70)\end{array}$ & $\begin{array}{c}27.5-70 \\
(57.70 \pm 12.94)\end{array}$ & $\begin{array}{c}47.5-87.5 \\
(61.25 \pm 13.22)\end{array}$ \\
\hline VSL & $\begin{array}{c}150-220 \\
(194.37 \pm 23.63)\end{array}$ & $\begin{array}{c}155-230 \\
(190.90 \pm 21.88)\end{array}$ & $\begin{array}{c}170-255 \\
(202.14 \pm 27.90)\end{array}$ & $\begin{array}{c}95-222.5 \\
(182.5 \pm 42.93)\end{array}$ & $\begin{array}{c}135-225 \\
(177.14 \pm 33.64)\end{array}$ \\
\hline VSW & $\begin{array}{l}137.5-197.5 \\
(180 \pm 20.65) \\
\end{array}$ & $\begin{array}{c}150-212.5 \\
(177.95 \pm 17.63) \\
\end{array}$ & $\begin{array}{c}162.5-237.5 \\
(185.71 \pm 20.10) \\
\end{array}$ & $\begin{array}{c}87.5-210 \\
(177.08 \pm 39.81) \\
\end{array}$ & $\begin{array}{c}122.5-210 \\
(162.14 \pm 33.49)\end{array}$ \\
\hline ATL & $\begin{array}{c}95-170 \\
(123.05 \pm 25.33)\end{array}$ & $\begin{array}{c}122.5-197.5 \\
(169.37 \pm 25.49)\end{array}$ & $\begin{array}{c}200-332.5 \\
(247.67 \pm 38.85)\end{array}$ & $\begin{array}{c}55-257.5 \\
(193.54 \pm 68.74)\end{array}$ & $\begin{array}{c}135-350 \\
(202.5 \pm 76.52)\end{array}$ \\
\hline ATW & $\begin{array}{c}85-217.5 \\
(130 \pm 46.93)\end{array}$ & $\begin{array}{c}97.5-182.5 \\
(144.16 \pm 23.84)\end{array}$ & $\begin{array}{c}105-292.5 \\
(204.64 \pm 53.85)\end{array}$ & $\begin{array}{c}67.5-255 \\
(187.29 \pm 57.46)\end{array}$ & $\begin{array}{c}90-275 \\
(163.75 \pm 59.97)\end{array}$ \\
\hline PTL & $\begin{array}{c}82.5-190 \\
(126.11 \pm 35.31)\end{array}$ & $\begin{array}{c}120-220 \\
(176.04 \pm 28.65)\end{array}$ & $\begin{array}{c}152.5-530 \\
(278.03 \pm 113.43)\end{array}$ & $\begin{array}{c}75-287.5 \\
(219.37 \pm 73.72)\end{array}$ & $\begin{array}{c}130-400 \\
(214.68 \pm 101.06)\end{array}$ \\
\hline PTW & $\begin{array}{c}70-185 \\
(123.33 \pm 38.60)\end{array}$ & $\begin{array}{c}102.5-187.5 \\
(150.62 \pm 24.84)\end{array}$ & $\begin{array}{c}157.5-282.5 \\
(208.92 \pm 37.38)\end{array}$ & $\begin{array}{c}70-260 \\
(188.54 \pm 57.18)\end{array}$ & $\begin{array}{c}90-302.5 \\
(157.81 \pm 63.54)\end{array}$ \\
\hline RVGL & $\begin{array}{c}260-370 \\
(318.88 \pm 37.56)\end{array}$ & $\begin{array}{c}230-540 \\
(420.83 \pm 109.49)\end{array}$ & $\begin{array}{c}230-420 \\
(320.71 \pm 57.70)\end{array}$ & $\begin{array}{c}160-520 \\
(404.16 \pm 121.68)\end{array}$ & $\begin{array}{c}290-530 \\
(387.5 \pm 104.43)\end{array}$ \\
\hline RVGW & $\begin{array}{c}80-160 \\
(118.88 \pm 28.03)\end{array}$ & $\begin{array}{c}80-150 \\
(106.66 \pm 21.46)\end{array}$ & $\begin{array}{c}90-200 \\
(132.85 \pm 32.20)\end{array}$ & $\begin{array}{c}50-150 \\
(108.33 \pm 32.98)\end{array}$ & $\begin{array}{c}60-160 \\
(112.5 \pm 31.95)\end{array}$ \\
\hline LVGL & $\begin{array}{c}320-420 \\
(372.22 \pm 32.70)\end{array}$ & $\begin{array}{c}240-550 \\
(410.83 \pm 98.66)\end{array}$ & $\begin{array}{c}230-440 \\
(335.71 \pm 22.39)\end{array}$ & $\begin{array}{c}170-550 \\
(388.33 \pm 103.73)\end{array}$ & $\begin{array}{c}260-550 \\
(352.5 \pm 104.43)\end{array}$ \\
\hline LVGW & $\begin{array}{c}60-170 \\
(120-32.78)\end{array}$ & $\begin{array}{c}60-150 \\
(99.16 \pm 22.34)\end{array}$ & $\begin{array}{c}80-170 \\
(126.42 \pm 22.39)\end{array}$ & $\begin{array}{c}60-140 \\
(106.66 \pm 25.70)\end{array}$ & $\begin{array}{c}50-150 \\
(102.5 \pm 30.11)\end{array}$ \\
\hline OL & $\begin{array}{c}100-157.5 \\
(127.77 \pm 18.97)\end{array}$ & $\begin{array}{c}75-192.5 \\
(133.54 \pm 32.49)\end{array}$ & $\begin{array}{c}80-157.5 \\
(109.46 \pm 23.72)\end{array}$ & $\begin{array}{c}57.5-155 \\
(112.29 \pm 27.77)\end{array}$ & $\begin{array}{c}40-190 \\
(116.87 \pm 43.52)\end{array}$ \\
\hline OW & $\begin{array}{c}100-150 \\
(121.38 \pm 15.56)\end{array}$ & $\begin{array}{c}82.5-185 \\
(129.58 \pm 29.95)\end{array}$ & $\begin{array}{c}92.5-177.5 \\
(130.35 \pm 27.36)\end{array}$ & $\begin{array}{c}47.5-142.5 \\
(112.29 \pm 25.77)\end{array}$ & $\begin{array}{c}90-140 \\
(118.125 \pm 17.35)\end{array}$ \\
\hline EL & $\begin{array}{c}28.87-37.5 \\
(31.375 \pm 3.08)\end{array}$ & $\begin{array}{l}29.42-34.42 \\
(31.74 \pm 1.50)\end{array}$ & $\begin{array}{l}28.87-38.05 \\
(33.02 \pm 2.69)\end{array}$ & $\begin{array}{c}26.37-37.5 \\
(32.21 \pm 2.84)\end{array}$ & $\begin{array}{c}26.65-32.5 \\
(29.60 \pm 1.73)\end{array}$ \\
\hline EW & $\begin{array}{c}13.6-16.37 \\
(14.6 \pm 0.86\end{array}$ & $\begin{array}{c}14.15-16.1 \\
(31.74 \pm 1.50)\end{array}$ & $\begin{array}{c}12.2-17.2 \\
(15.28 \pm 1.32)\end{array}$ & $\begin{array}{c}14.7-18.32 \\
(16.33 \pm 1.03)\end{array}$ & $\begin{array}{l}14.42-18.05 \\
(15.61 \pm 1.16)\end{array}$ \\
\hline
\end{tabular}


TABLE I (continuation)

\begin{tabular}{|c|c|c|c|c|c|}
\hline & $\begin{array}{c}\text { Durango } \\
n=9 \\
\text { (CNHE 3874- } \\
\text { 3875) }\end{array}$ & $\begin{array}{c}\text { Puebla } \\
n=12 \\
\text { (CNHE 3872- } \\
\text { 3873) }\end{array}$ & $\begin{array}{l}\text { Nuevo León } \\
n=14 \\
\text { (CNHE3871) }\end{array}$ & $\begin{array}{c}\text { Zacatecas } \\
n=12 \\
(\mathrm{CNHE3870})\end{array}$ & $\begin{array}{c}\text { Mexico } \\
n=8 \\
\text { (CNHE10978) }\end{array}$ \\
\hline DPAATPAB & $\begin{array}{c}500-680 \\
(623.33 \pm 69.46)\end{array}$ & $\begin{array}{c}490-760 \\
(630.83 \pm 91.30)\end{array}$ & $\begin{array}{c}500-700 \\
(594.29 \pm 62.48)\end{array}$ & $\begin{array}{c}310-750 \\
(580 \pm 143.96)\end{array}$ & $\begin{array}{c}470-740 \\
(617.5 \pm 90.67)\end{array}$ \\
\hline DPAPTPAB & $\begin{array}{c}670-830 \\
(754.44 \pm 54.33)\end{array}$ & $\begin{array}{c}570-850 \\
(745 \pm 101.04)\end{array}$ & $\begin{array}{c}550-860 \\
(710 \pm 95.83)\end{array}$ & $\begin{array}{c}390-960 \\
(725.83 \pm 177.78)\end{array}$ & $\begin{array}{c}640-1000 \\
(763.75 \pm 135.74)\end{array}$ \\
\hline DRVGPAB & $\begin{array}{c}920-1100 \\
(1002.22 \pm 78.06)\end{array}$ & $\begin{array}{c}800-1250 \\
(1045 \pm 152.10)\end{array}$ & $\begin{array}{c}800-1300 \\
(997.85 \pm 124.23)\end{array}$ & $\begin{array}{c}490-1300 \\
(1049.16 \pm 265.34)\end{array}$ & $\begin{array}{c}910-1490 \\
(1107.14 \pm 226.62)\end{array}$ \\
\hline DRVGPPB & $\begin{array}{c}890-1160 \\
(1035.55 \pm 97.09)\end{array}$ & $\begin{array}{c}630-820 \\
(730 \pm 53.42)\end{array}$ & $\begin{array}{c}360-1000 \\
(692.14 \pm 161.20)\end{array}$ & $\begin{array}{c}410-1340 \\
(1013.33 \pm 295.67)\end{array}$ & $\begin{array}{c}780-970 \\
(888.57 \pm 63.62)\end{array}$ \\
\hline DLVGPAB & $\begin{array}{c}790-1060 \\
(978.88 \pm 81.61)\end{array}$ & $\begin{array}{c}750-1340 \\
(1029.16 \pm 166.92)\end{array}$ & $\begin{array}{c}880-1230 \\
(1018.57 \pm 111.55)\end{array}$ & $\begin{array}{c}510-1320 \\
(1062.5 \pm 270.89)\end{array}$ & $\begin{array}{c}950-1500 \\
(1137.14 \pm 231.35)\end{array}$ \\
\hline DLVGPPB & $\begin{array}{c}850-1290 \\
(993.33 \pm 140.4)\end{array}$ & $\begin{array}{c}650-800 \\
(752.5 \pm 44.33)\end{array}$ & $\begin{array}{c}270-990 \\
(680.71 \pm 182.64)\end{array}$ & $\begin{array}{c}410-1450 \\
(1055.83 \pm 315.08)\end{array}$ & $\begin{array}{c}830-1000 \\
(888.57 \pm 60.94)\end{array}$ \\
\hline DOPAB & $\begin{array}{c}760-980 \\
(882.22 \pm 68.69)\end{array}$ & $\begin{array}{c}700-1090 \\
(908.33 \pm 119.15)\end{array}$ & $\begin{array}{c}680-1090 \\
(925 \pm 105.00)\end{array}$ & $\begin{array}{c}420-1220 \\
(945.83 \pm 248.39)\end{array}$ & $\begin{array}{c}780-1380 \\
(980 \pm 231.33)\end{array}$ \\
\hline $\begin{array}{c}\text { FORM } \\
\text { OF THE } \\
\text { TESTIS }\end{array}$ & $\begin{array}{l}\text { Lobed }(\mathrm{n}=6) ; \text { oval } \\
\qquad(\mathrm{n}=3)\end{array}$ & Lobed $(n=12)$ & $\begin{array}{l}\text { Lobed }(n=3) ; \\
\text { reniform }(n=2) ; \\
\text { rosette }(n=9)\end{array}$ & $\begin{array}{l}\text { Lobed }(n=9) ; \\
\text { triangular }(n=3)\end{array}$ & $\begin{array}{c}\text { Lobed }(\mathrm{n}=7) ; \text { oval } \\
\qquad(\mathrm{n}=1)\end{array}$ \\
\hline
\end{tabular}

\section{STATISTICAL ANALYSIS}

To remove the effect of sample size, the measurements were Ln transformed and manually standardized by $\mathrm{z}=[(\mathrm{x}-\mu) / \sigma]$, where $\mu$ is the average value and $\sigma$ is the standard deviation of each trait. Multinormality and kurtosis were tested by the Mardia method (Mardia 1970) and corrected by the Bonferroni method. The standardized variables were transformed using principal component analysis (PCA) of all the variables (Holm 1979).

A simple PCA would not be appropriate to obtain a clear picture of between-population variation because PCA aims to summarize the overall variability between individuals, which includes both the divergence among and within populations (Fisher 1936). By contrast, discriminant analysis (DA) defines a model in which all variation is partitioned among and within population components and yields synthetic variables that maximize the first while minimizing the second variability source. However, DA requires independence between variables in which all the autocorrelated attributes result in a lower allocation of individuals within the corresponding populations, while PCA assumes correlations identifying the largest contribution of variables to each component without eliminating the rest (Lachenbruch and Goldstein 1979). We compared the populations through discriminant analysis of principal component (DAPC), a new methodological approach that retains all the assets of DA without its limitations (e.g. Stewart et al. 2014, Deperi et al. 2018, Cejnar et al. 2018). Data transformed by PCA in a prior step are perfectly uncorrelated variables used by DA (Jombart et al. 2010). The statistical analyses were performed using the software STATISTICA v. 10.0 (StatSoft 2011) and Past (Paleontological Statistics; Hammer et al. 2001). 


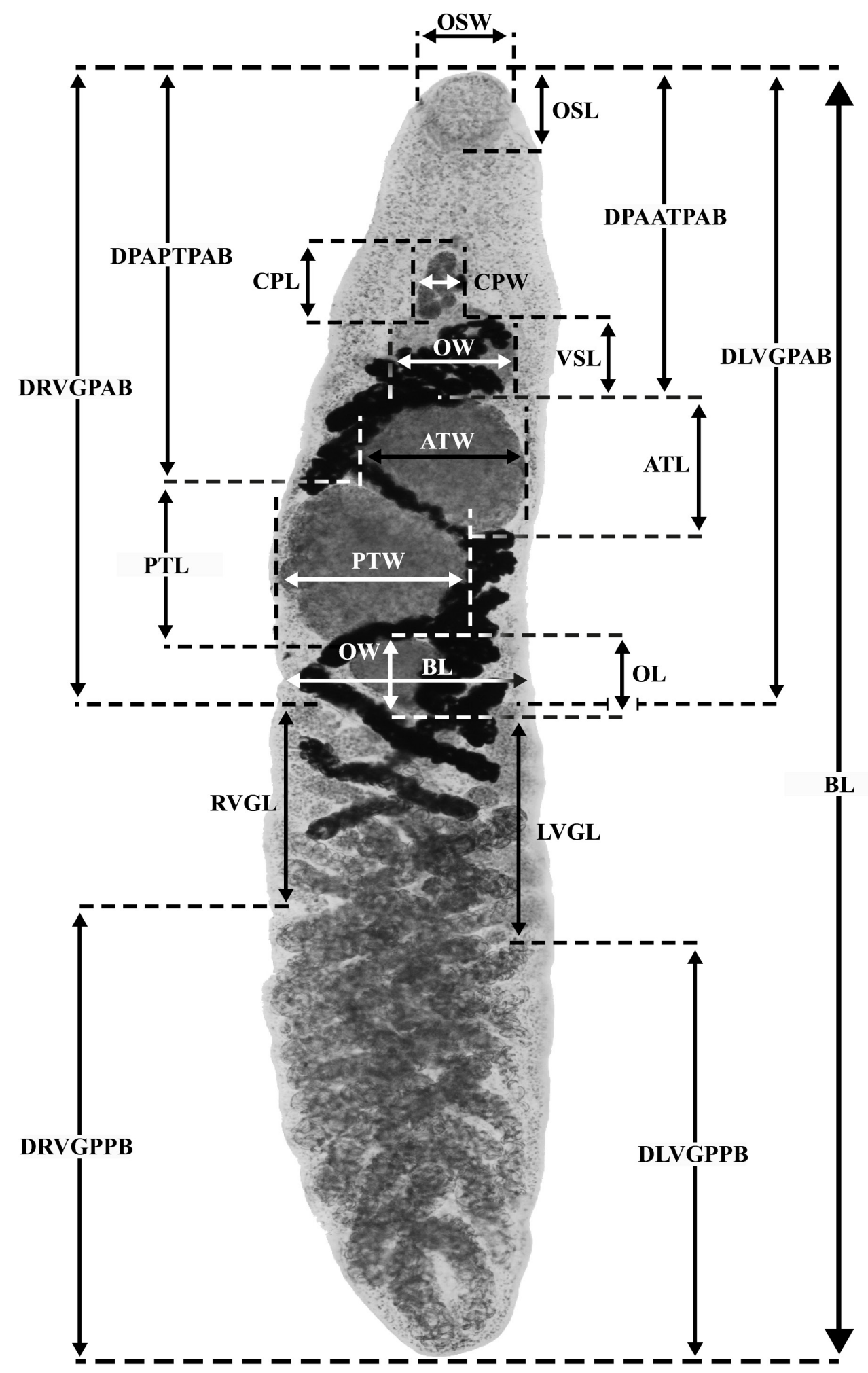

Figure 1 - Dicrocoelium rileyi. Worm showing morphometric features used as variables. 


\section{RESULTS}

All specimens studied were assigned to $D$. rileyi, a bile-ducts and gall-bladder parasite of T. brasiliensis, by having a lancet-shaped body, elongate, unarmed tegument, oral sucker smaller than the ventral sucker, intestinal caeca that did not exceed the vitelline glands, and a dorsally located ovary and posterior testis. In the morphological review of the specimens of the five populations under study, there was a modification of the position of the vitelline glands since in the original description of the species, these glands are located below the equator, while in some of the specimens studied by us, some of the vitelline follicles pass over the equator.

The testes have different forms (lobed, oval, rosette, triangular and reniform) and can be located extra- or intracaecally (Figure 2 and Table I). The ovary is intracaecal, round to oval shaped, with lobed edges. The ovary is located indistinctly under the anterior or posterior testis. The ovary shape is round to oval with lobed edges. We also detected variations in the size of the ovary with respect to the testes in individuals from different populations; in Mexico and Nuevo Leon, the ovary was smaller than the testes. Meanwhile, in specimens form Durango (5 of 9 individuals) and Zacatecas (1), this relationship was inverted. In the six specimens from Puebla, the gonads were the same size.

The measurements of the morphological features of the specimens from the five localities were similar in range. However, the specimens from Zacatecas had some differences, such as total length (1.05 to 3.07), while for the other localities, the range was from 1.45 to 2.85 .
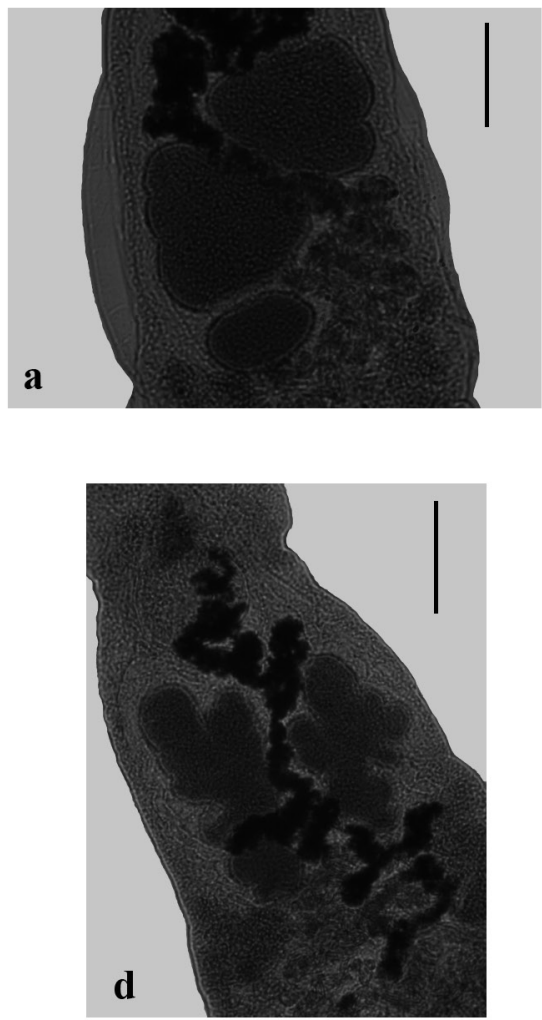
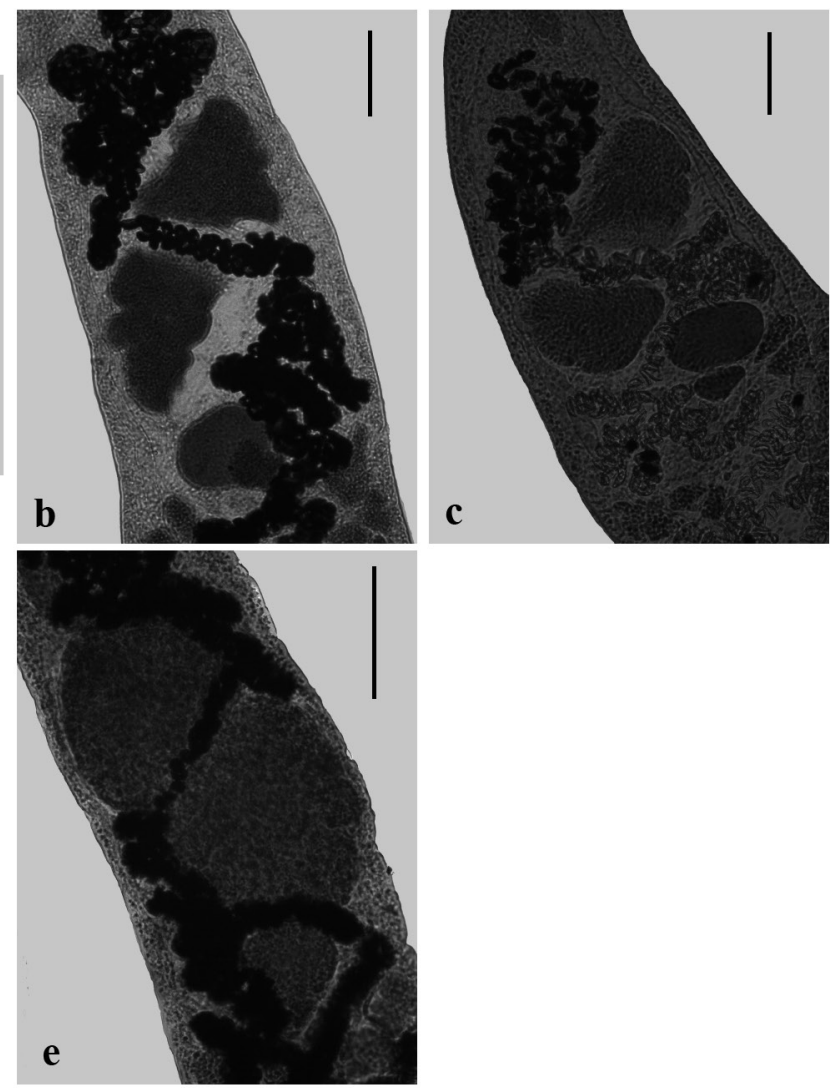

Figure 2 - Forms of the testis: a) lobed [Puebla, CNHE 3872], b) triangular [Zacatecas, CNHE 3870], c) reniform [Nuevo León, CNHE 3871], d) rosette [Nuevo León, CNHE 3871], e) oval [Durango, CNHE 3875]. 
The 27 evaluated traits assumed a multinormal distribution as shown by the Mardia method (Skewness coefficient $=417.4 ; \mathrm{df}=3654 ; \mathrm{p}=$ $0.023<$ Bonferroni $=0.0019$. Kurtosis $=766.9, \mathrm{p}$ $=0.132$ ). PCA showed a $79 \%$ cumulative variance with the first six principal components (1.18 to 12.81 eigenvalues) (Table II). The first component is correlated with DLVGPAB and DOPAB, and the second is only correlated with DLVGPPB. The third is only correlated with VSW, the fourth is correlated with EW, the fifth is correlated OL and the sixth is correlated OSW. The first and sixth components have both positive and negative correlation values ( $r> \pm 0.75$ ) with the mentioned traits, but these components are not useful for defining the groups. Therefore, as a better classification of individuals within the populations, we used DAPC for the 27 components generated in the previous analyses.

DAPC shows significant differences among populations $\left(\mathrm{F}_{(4,24)}=189.66, \mathrm{p}<0.0001\right)$, with exceptions between 2-4 and 3-5 (Figure 2). All differences are explained by three factors ( $88 \%$ of explained variance) associated with the $\mathrm{C} 2$ principal component (highly correlated with DLVGPPB), C3 principal component (highly correlated with VSW), C4 principal component (highly correlated with EW), C6 principal component (highly correlated with OSW), C7 principal component (highly correlated with CPL), C10 principal component (highly correlated with EW), C12 principal component (highly correlated with OL) and C23 principal component (highly correlated with BL) (Wilks mean value $=0.3964 \pm 0.176, \mathrm{p}<0.05$ )

\section{DISCUSSION}

Following Caspeta-Mandujano et al. (2017) and Macy (1931), the specimens studied were assigned to Dicrocoelium rileyi due to having a body that was eloangate and lanceolate, an unspined tegument, an oral sucker slightly smaller than the ventral sucker, intestinal ceca not extending posterior to the vitellaria, testes much larger than the ovary and the vitellogenic gland not extending over one-sixth of the body length.

PCA showed that the morphological variation among individuals was determined by the distances of the left vitellogenic gland and the ovary from the anterior and posterior body ends, the ventral and oral sucker width, and the egg width and ovary length. These traits explained both sources of variation (within and among populations) but could not establish an appropriate grouping. On the other hand, DAPC could be used to define clusters of individuals and to unravel possibly complex structures existing among clusters, such

TABLE II

Canonical discriminant function coefficients of divergent morphological features among populations. Cumm. Var.: Cumulative variance.

\begin{tabular}{|c|c|c|c|c|c|c|}
\hline Morphological features & DF 1 & DF 2 & DF 3 & $\lambda$ Wilks & $\mathbf{X}^{2}$ & p value \\
\hline DLVGPPB & -0.56938 & 1.24995 & 0.24199 & 0.1324 & 39.29 & $<0.0001$ \\
\hline VSW & -0.49217 & 0.67515 & -2.28645 & 0.2648 & 16.65 & $<0.0001$ \\
\hline EW & -0.51550 & 0.43426 & -2.69274 & 0.2062 & 23.089 & $<0.0001$ \\
\hline OSW & -0.41942 & 0.33074 & -3.28163 & 0.4326 & 7.86 & 0.0003 \\
\hline CPL & -0.64700 & 0.26397 & -0.61824 & 0.4616 & 6.99 & 0.0007 \\
\hline OL & -0.49880 & 0.63569 & 1.79949 & 0.6379 & 3.405 & 0.0242 \\
\hline BL & -0.68983 & -0.87487 & 0.15754 & 0.524 & 5.4467 & 0.0028 \\
\hline Eigenvalue & 8.98734 & 7.00169 & 3.760245 & & & \\
\hline Cum. Var. & 40.08 & 71.13 & 88.08 & & & \\
\hline
\end{tabular}




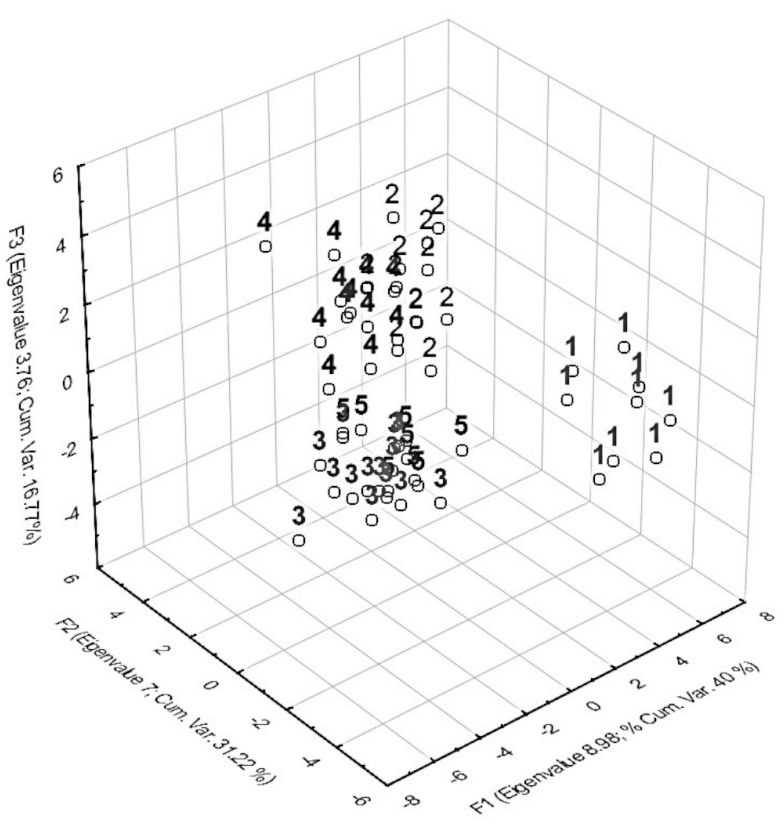

Figure 3 - Visualization space for Discriminant Analysis of Principal Component (DAPC). On the three first resultant factors (F1, F2 and F3) with the eigenvalues and the cumulative variance (\%), of the five populations from Mexico of Dicrocoelium rileyi $($ Durango $=\mathbf{1}$; Mexico State $=\mathbf{5}$; Nuevo Leon $=\mathbf{3}$; Puebla $=\mathbf{2}$; Zacatecas $=4$ ) parasitizing Tadarida brasiliensis.

as hierarchical clustering and clinal differentiation (Jombart et al. 2010). With this method, we differentiated three groups (Figure 3): the first group consisted of the populations of Zacatecas and Puebla, the second consisted of those of from Mexico State and Nuevo Leon, and the third consisted of the population from Durango, showing increased values of diagnostic traits. In agreement with the PCA results, the differences found between the populations were explained by the distance from the left vitellogenic gland to the tail of the body, the ventral and oral sucker width, and the egg width and ovary length. The coincidence between the PCA and DACP results indicates that these five attributes can be considered to be diagnostic to differentiate the populations. DACP showed two other diagnostic attributes: cirrus pouch length and body length, excluding the distances of the left vitellogenic gland to the anterior body end. Thus, in some cases these two traits can also be considered.

The morphological and morphometric variations observed may be due to several factors, such as the type of fixation and preparation of the specimens under study since the processing of the samples can vary according to the person who carries it out. This factor can lead to a certain shrinkage or elongation of the organisms, effecting the measurements of morphological traits (Poulin 2009, Barger and Wellenstein 2015). In the present study, the materials of $D$. rileyi from Nuevo Leon, Zacatecas, Durango and Puebla were processed by the same person (Guzmán-Cornejo et al. 2003), while for the specimens from Mexico State, the same method was followed to avoid morphological and morphometric variations. Additionally, variations may have resulted from multiple factors that affect and regulate the microevolutionary processes of parasite species (Paterson and Gray 1997). Some of these factors are: definitive host specificity (i.e., different host species, host's immune system), type of intermediate hosts, complexity of life cycles, and the abundance and prevalence of each of the parasite populations. These variations may produce a variety of phenotypes, such as differences in body size or fecundity (Poulin 1998, 2007, Criscione et al. 2005, Alemán-Muñoz et al. 2013), and the spatial distance between the parasite populations may lead to genetic divergence and thus to phenotypic differences (Criscione et al. 2005, Chibwana and Nkwengulila 2009).

In the case of Digenea, the most speciesdiagnostic features are the body proportions or the shape and location of the internal organs. Phenotypic variations may be induced by differences in the intensity of infection ("crowding effect") and in the host's identity ("host-induced variation"). These phenotypic effects may lead to species-specific variation, resulting in misidentification (Hildebrand et al. 2015, Nolan and Cribb 2005, Stunkard 1957). 
In conclusion, we consider that the morphological traits of $D$. rileyi are variable among the populations studied due to interlocality variation; a first analysis of populations led us to consider that some of the specimens in the different localities could represent different species. However, a close examination of the morphology did not favor this conclusion. Nevertheless, a molecular analysis is necessary to define whether the populations represented one or several species (Hildebrand et al. 2015, Chibwana and Nkwengulila 2009). Finally, this is the first report of $D$. rileyi in Mexico State, expanding its geographic location.

\section{ACKNOWLEDGMENTS}

We thank to Luis García-Prieto CNHE, Mexico City, for the loan of specimens. Thanks is due to Alberto E. Rojas-Martínez for their help in the collecting and identification of bats.

\section{AUTHOR CONTRIBUTIONS}

JFO and IEC collected the data and conceived the ideas. POA and IEC designed methodology and analyzed the data. JFO and IEC made the figures. All authors wrote the draft of manuscript, and contributed critically to the drafts and gave final approval for publication.

\section{REFERENCES}

AL-ZANBAGI NA AND HASSAN HA. 2013. A multivariate analysis of some Digenean species collected from several red sea fishes in Saudi Arabia. Lif Sci J 10: 1244-1255.

ALEMÁN-MUÑOZ F, PULIDO-FLORES G, MONKS S AND FALCÓN-ORDAZ J. 2013. Análisis morfométrico de Glypthelmins quieta (Stafford, 1900) Stafford, 1905 (Digenea: Macroderoididae) en la Reserva de Metztitlan, Hidalgo, Mexico. In: Pulido-Flores G and Monks S (Eds), Estudios científicos en el estado de Hidalgo y zonas aledañas, Nebraska: Zea Books, Lincoln, Nebraska, USA, p. 41-58.

BAER JG. 1971. Trématodes de rongeurs récoltés en Côte d'Ivoire. Parasitol Res 37: 226-254.

BARGER M AND WELLENSTEIN D. 2015. Morfological Confirmation of Homalometron (Trematoda:
Apocreadiidae) Species in Fresh water Fishes in Southeastern Texas, USA, with Description of Two Species. Comp Parasitol 82: 248-253.

BEN-ABDALLAH LG, TRIGUI EL MENIF N AND MAAMOURI F. 2008. The Morphology and behaviour of Cercaria lata Lespés, 1857 (Digenea, Faustulidae) from the Mediterranean clam Tapes decussata (L.). J Helminthol 83: 69-76.

BRAY RA AND CLERS SA. 1992. Multivariate analyses of metrical features in the Lepidapedon elongatum (Lebour, 1908) species-complex (Digenea, Lepocreadiidae) in deep and shallow water gadiform fishes of the NE Atlantic. Syst Parasitol 21: 223-232.

CAFFARA M, LOCKE SA, CRISTANINI C, DAVIDOVICH N, MARKOVICH MP AND FLORAVANTI ML. 2016. A combined Morfometric and Molecular Approach to Identifying Metacercaria of Euclinostomun heterostomun (Digenea: Clinostomidae). J Parasitol 102: 239-248.

CASPETA-MANDUJANO JM ET AL. 2017. Helmintos parásitos de murciélagos en México. Universidad Autónoma del Estado de Hidalgo, 277 p.

CEJNAR P, KUCKOVA S, PROCHAZKA A, KARAMONOVA L AND SVODOVA B. 2018. Principal component analysis of normalized full spectrum mass spectrometry data in multiMS-toolbox: An effective tool to identify important factors for classification of different metabolic patterns and bacterial strains. Rapid Commun Mass SP 32: 871-881.

CHIBWANAFD AND NKWENGULILA G. 2009. Variation in the morphometrics of Diplostomid Metacercarie (Digenea: Trematode) infecting the catfish, Clarias gariepinus in Tazania. J Helminthol 84: 61-70.

CRIBB TH AND SPRATT DM. 1992. Dicrocoeliidae (Trematoda: Digenea) of Australian mammals with description of Dicrocoeliu mantechini n. sp., Athesmioides aiolos ng, n. sp. and Platynosomum burrman n. sp. Syst Parasitol 21: 211-222.

CRISCIONE CD, POULIN R AND BLOUIN MS. 2005. Molecular ecology of parasites: elucidating ecological and microevolutionary processes. Mol Ecol 14: 2247-2257.

FISHER RA. 1936. The use of multiple measurements in taxonomic problems. Ann Eugen 7: 179-188.

DEPERI SI, TAGLIOTTI ME, BEDOGNI MC, MANRIQUECARPINTERO NC, COOMBS J, ZHANG RF, DOUCHES D AND HUARTE MA. 2018. Discriminant analysis of principal components and pedigree assessment of genetic diversity and population structure in a tetraploid potato panel using SNPs. PLoS ONE 13: e0194398.

GUZMÁN-CORNEJO C, GARCÍA-PRIETO L, PÉREZPONCE DE LEÓN G AND MORALES-MALACARA JB. 2003. Parasites of Tadarida brasiliensis mexicana (Chiroptera: Molossidae) from Arid Regions of Mexico. Comp Parasitol 70: 11-25. 
HAMMER O, HARPER DAT AND RYAN PD. 2001. PAST: Paleontological statistics software package for educacion and data analysis. Paleontología Electrónica 4: 9.

HILDEBRAND J, ADAMCZYK M, LASKOWSKI Z AND ZALESNY G. 2015. Host dependent morphology of Isthmio phoramelis (Schrank, 1788) Luhe, 1909 (Digenea, Echinostomatinae) morphological variation vs. molecular stability. Parasit Vectors 8: 481.

HOLM S. 1979. A simple sequentially rejective multiple test procedure. Scand J Stat 6: 65-70.

HINAIDY HK. 1983. Dicrocoelium suppererino mennovum (syn. D. orientalis Sudarikov et Ryjikov 1951), einneuer Trematode für die Parasitenfauna Österreichs. Zoonoses and Public Health 30: 576-589.

JAMES FC AND MCCULLOCH CE. 1990. Multivariate Analysis in Ecology and Systematics: Panacea or Pandora's Box? Annu Rev Ecol Syst 21: 129-166.

JOMBART T, DEVILLARD S AND BALLOUX F. 2010. Discriminant analysis of principal components: a new method for the analysis of genetically structured populations. BMC Genet 11: 94.

LACHENBRUCH PA AND GOLDSTEIN M. 1979. Discriminant analysis. Biometrics 35: 69-85.

MACY RW. 1931. New Bat Trematodes of The Genera Plagiorchis, Limatulum, and Dicrocoelium. J Parasitol 18: 28-33.

MARDIA KV. 1970. Measures of multivariate skewness and kurtosis with applications. Biometrika 57: 519-530.

NOLAN MJ AND CRIBB TH. 2005. The use and implications of ribosomal DNA sequencing for the discrimination of digenean species. Adv Parasit 60: 101-163.

OTACHI EO, LOCKE SA, JIRSA F, FELLNER-FRANCK C AND MARCOGLIESE DJ. 2015. Morphometric and
Molecular analysis of Tylodelphys sp. Metacercarie (Digenea: Diplostomidae) from the vitreous humour of four fish species from Lake Naivasha, Kenya. J Helminthol 89: 404-414.

PANIN VJ AND ZHATKANBAEVA D. 1972. Dicrocoelium bykhowskajae sp n.-a new species of dicrocoelid from Gelochelidon nilotica. Izvestiya. Akad Nauk Kazakh. SSR 3: 46-47.

PATERSON A AND GRAY RD. 1997. Host-parasite cospeciation, host switching, and missing the boat. In: Clayton DH and Moore J (Eds), Host-parasite evolution. General Principles and avian model. New York: Oxford University Press, New York, USA, p. 473.

POJMANSKA T. 2008. Family Dicrocoeliidae, 1899. In: Bray RA, Gibson DI and Jones A (Eds), Keys to the Trematoda, London: CAB International and Natural History Museum, London, UK, p. 233-260.

POULIN R. 1998. Evolutionary Ecology of Parasites: from Individuals to communities. London: Chapman and Hall, 209 p.

POULIN R. 2007. Evolutionary Ecology of Parasites, 2nd ed., Princeton: Princeton University Press, 212 p.

POULIN R. 2009. Morphological diversification in different trematode lineages: body size, host type, or time? Parasitology 136: 85-92.

STATSOFT INC. 2011. STATISTICA (data analysis software system). Version 10. 0, USA. URL http://www. statsoft. com.

STEWART S, IVY MA AND ANSLYN EV. 2014. The use of principal component analysis and discriminant analysis in differential sensing routines. Chem Soc Rev 43: 70-84.

STUNKARD HW. 1957. Intraspecific variation in parasitic flatworms. Syst Zool 6: 7-18. 